\title{
FERTILIZER AND STOCKING RATES ON TWO KING COUNTRY SOILS
}

\author{
M. B. O'CONNOR \\ Ruakura Agricultural Research Centre, Hamilton
}

\author{
P. J. TONKIN*, T. E. LUDECKE $\dagger$ \\ Lincoln College, Canterbury
}

\begin{abstract}
Parent materials such as volcanic ash and sedimentary siltstone and sandstone form soils which differ markedly in their physical and chemical properties. In stocking $\times$ fertilizer rate trials on two families of soils, Te Kuiti-Tumutumu (volcanic ash) and Mahoenui-Mangatea (siltstonesandstone), the former showed marked response to increasing rates of superphosphate in terms of pasture availability and animal production but -the latter showed negligible response above the lowest rate $(250 \mathrm{~kg} / \mathrm{ha})$. Responses to superphosphate were apparent on Te Kuiti-Tumutumu only at the high stocking rate. Sward composition showed no measurable improvement with the application of superphosphate. Manage ment practices were undoubtedly important in this respect. Differential 'topdressing should be practised where feasible. When soil test levels for phosphate are medium to low, Te Kuiti-Tumutumu soils should receive at least $500 \mathrm{~kg} / \mathrm{ha} / \mathrm{yr}$ of superphosphate, Mahoenui-Mangatea soils $250 \mathrm{~kg} / \mathrm{ha} / \mathrm{yr}$. Stocking rates and management practices must be such as to allow full utilization of the additional pasture grown.
\end{abstract}

\section{INTRODUCTION}

LITTLE WORK has been undertaken in New Zealand to determine the potential of our hill country and information is urgently needed on stock carrying capacities and fertilizer requirements of such land. In 1966 a project was initiated by the Ministry of Agriculture and Fisheries in the Te Kuiti district. The area chosen for study was valuable in that the soil pattern present was representative of large areas of hill soils in the central part of North Island. Originally the area was cleared from bush after the 1914-18 war and was settled for dairy farming. Later it reverted

*Formerly Soil Bureau, DSIR, Hamilton.

†Formerly Ruakura Agricultural Research Centre, Hamilton. 
to scrub and blackberry and became an uneconomic unit. It was taken over by the present owner in 1954, cleared, and an 'average $300 \mathrm{~kg} / \mathrm{ha}$ of superphosphate applied annually far 13 years.

Investigations into the pattern of soil distribution, physical and chemical differences between soils, and fertilizer responses in terms of animal production (3 years' data) are summarized in this paper.

\section{TOPOGRAPHY AND PARENT MATERIALS}

The research area consists of a hill unit of 23 'ha situated $20 \mathrm{~km}$ south of Te Kuiti on the Te Kuiti-Taumarunui highway.

The hills are formed of layered siltstone and sandstone with a mantle of volcanic ashes on ridges and north-west slopes (Fig. 1).

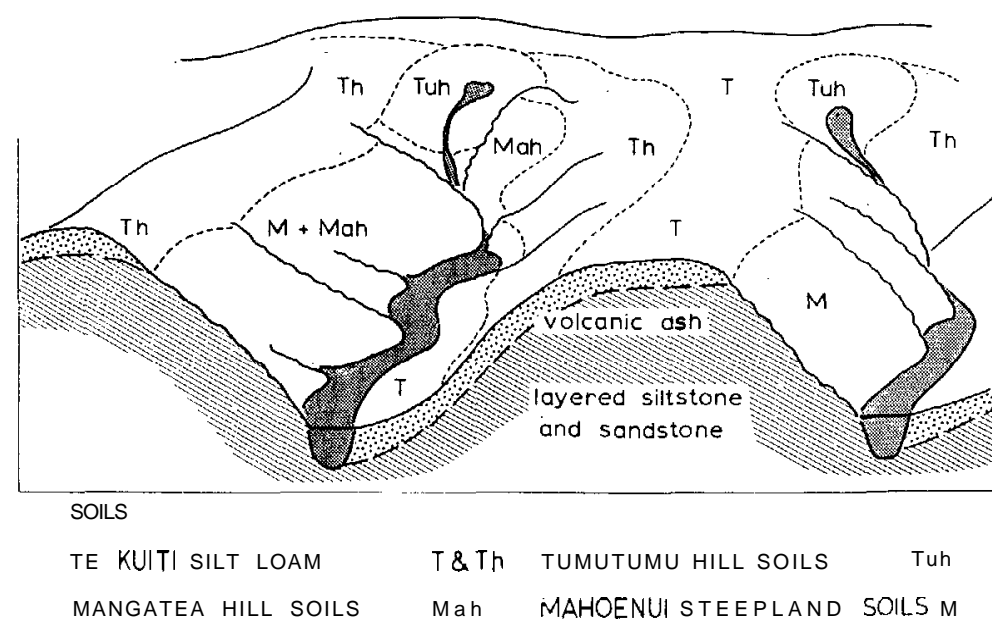

FIG. 1: Parent materials and soil distribution pattern on the Te Kuiti Research Area.

The amount of ash present depends on the slope:

Flat to undulating - all horizons consist of volcanic ash

10-30

- thin ash veneer in the upper horizons only

$>30$

- ash eroded off and silstone and sandstone often exposed. 


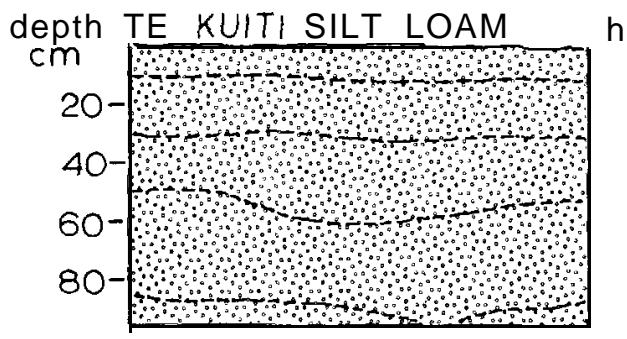

horizon texture

A si.l.

B 2.1 si. 1.

II $\mathrm{B}$ 2-2 si.l

प्र si.l.

III $\mathrm{s}$. 1.

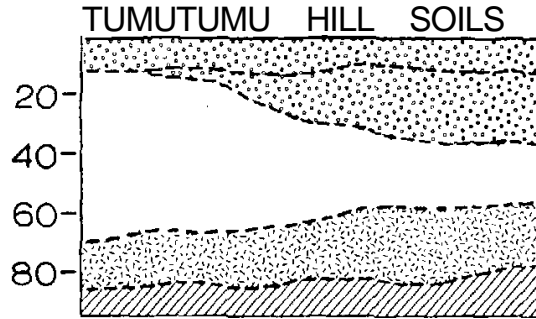

A sil.

B 2-I si.l.

I $\mathrm{B}$ 2-2 si.l.

IC 1 sil. or

II $\mathrm{C} 2$

cy.l.

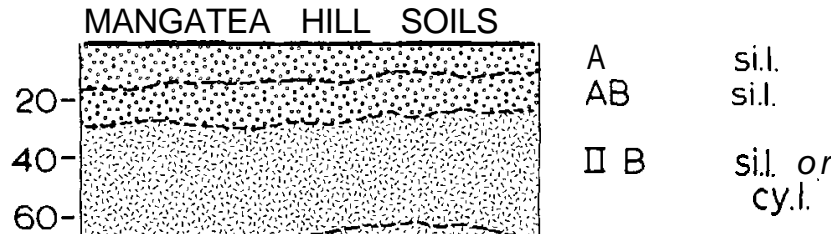

$80-,+-4$ -

MAHOENUI STEEPLAND SOILS

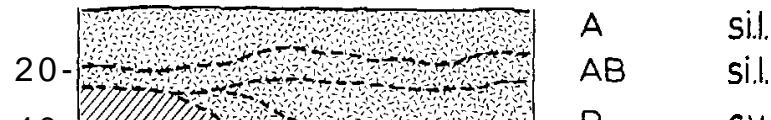

40 -

60

80

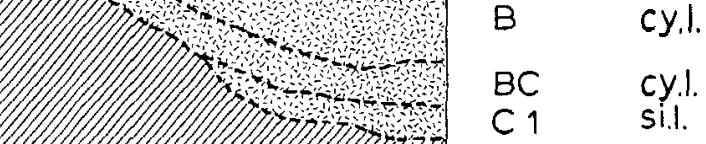

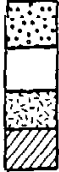

volcanic ash

siltstone colluvium \& volcanic ash

siltstone colluvium

siltstone

Fig. 2: Soil parent materials, horizon development and thickness and soil texture for the four mapping units, 
TABLE 1: GENERALIZED PROFILE DESCRIPTIONS FROM THE MAIN SOIL MAPPING UNITS

\begin{tabular}{|c|c|c|c|c|}
\hline Horizon & Te Kuiti Silt Loam & $\begin{array}{c}\text { Tumutumu } \text { Hill } \\
\text { Complex }\end{array}$ & $\begin{array}{l}\text { Mangatea Hill Soil } \\
\text { Complex }\end{array}$ & $\begin{array}{c}\text { Mahoenui Hill Soil } \\
\text { Complex }\end{array}$ \\
\hline A & $\begin{array}{l}\text { Black, silt loams, very } \\
\text { friable porous, crumb- } \\
\text { structured (ash) }\end{array}$ & $\begin{array}{l}\text { Black, silt loam, very } \\
\text { friable porous, crumb- } \\
\text { structured (ash) }\end{array}$ & $\begin{array}{l}\text { Greyish brown silt loam, } \\
\text { friable, crumb-structured } \\
\text { (siltstone ash) }\end{array}$ & $\begin{array}{l}\text { Greyish brown silt loam, } \\
\text { friable, nut-structured (silt- } \\
\text { stone) }\end{array}$ \\
\hline B & $\begin{array}{l}\text { Brown silt loam, friable, } \\
\text { porous, crumb-structured } \\
\text { (ash) }\end{array}$ & $\begin{array}{l}\text { Brown silt loam, friable } \\
\text { or firm nut and fine l } \\
\text { blocky structure (silt- } \\
\text { stone and ash) }\end{array}$ & $\begin{array}{l}\text { Yellowish brown silt } \\
\text { oam or clay loam, firm, } \mathrm{f} \\
\text { fine blocky structure } \\
\text { (siltstone) }\end{array}$ & $\begin{array}{l}\text { Yellowish brown clay loam, } \\
\text { firm, fine blocky structure } \\
\text { (siltstone) }\end{array}$ \\
\hline c & Slightly compact (ash) & $\begin{array}{l}\text { Firm, compact (siltstone, } \\
\text { sandstone) }\end{array}$ & $\begin{array}{l}\text { Firm, compact (siltstone, } \\
\text { sandstone) }\end{array}$ & Siltstone on sandstone \\
\hline
\end{tabular}




\section{SOILS AND SOIL PATTERN}

An intensive soil survey was done on the area before commencing the trial. Soil mapping units were recognized by regular soil profile examinations and auger borings and include one soil type, two hill soil complexes, and one steepland soil complex. Brief profile descriptions of the four mapping units are shown in Table 1 and their distributions on Fig. 1. These units have been provisionally assigned to the Te Kuiti, Tumutumu, Mangatea and Mahoenui soil sets, respectively (N.Z. Soil Bureau, 1954). Of particular importance is the occurrence of soil complexes, mapping units in which soil properties such as depth alternate from shallow to deep over very short distances.

Variations in the soil parent materials, horizon development and thickness and soil texture for the four mapping units are summarized in Fig. 2, while brief profile descriptions are shown in Table 1.

Volcanic ash gives soil friability and crumb structure and generally a low bulk den\&y and a high water-holding capacity. Siltstone and sandstone impart properties of firmness and have a nutty to blocky structure, medium bulk density 'and a reduced water-holding capacity.

\section{ADDITIONAL SOIL PROPERTIES}

Major nutrient status of representative samples of the four mapping units is shown in Table 2. Phosphorus levels have been deleted owing to differential superphosphate applications.

TABLE 2: TOTAL NITROGEN AND EXCHANGEABLE CATIONS OF THE SOIL PROFILES

$(\mathrm{kg} / \mathrm{ha} / 70 \mathrm{~cm}$ air dry soil)

\begin{tabular}{lccrrc}
\hline & N & Ca & Mg & Na & \multicolumn{1}{c}{ K } \\
\hline Te Kuiti & 12000 & 2830 & 500 & 130 & 140 \\
Tumutumu & 14180 & 2810 & 470 & 70 & 970 \\
Mahoenui & 11500 & 4080 & 750 & 120 & 470 \\
Mangatea & 12730 & 3280 & 1010 & 270 & 580 \\
\hline
\end{tabular}

There is little difference between soils with the exception perhaps of a lower $\mathrm{K}$ content on Te Kuiti silt loam compared with the other soils.

The most important chemical difference is undoubtedly that of phosphate retention (Saunders, 196.5). This refers to the 
ability of soils to retain added phosphorus and is an index of the propensity of a soil to fix phosphorus. Te Kuiti silt loam has a phosphate retention of 90 to $100 \%$ as compared with 40 to $45 \%$ for Mahoenui silt loam. This difference is obviously very important on soils such as these which are inherently phosphorus deficient. However, pasture production differences between soils are unlikely to be due solely to chemical differences; physical properties as well as factors of aspect and slope plus grazing management are likely to be important determinants of pasture production.

\section{EXPERIMENTAL DETAILS}

For practical purposes of fencing and trial design, the mapping units were aggregated into two families: Te Kuiti-Tumutumu soils classed as yellow-brown loams (occupying $58 \%$ of the area) ; Mahoenui-Mangetea classed as yellow-brown earths (occupying $42 \%$ of the area). There were two trials, one on each of these soils. Basic experimental design is shown in Table 3. Each trial consisted of eighteen 0.5 ha paddocks.

TABLE 3: BASIC EXPERIMENTAL DESIGN AND TREATMENTS (3 Replications)

\begin{tabular}{ccccc}
\hline $\begin{array}{c}\text { Superphosphate } \\
\text { Treatment } \\
(k g / h a / y r)\end{array}$ & $\begin{array}{c}\text { Te Kuiti } \\
\text { Low (LS) } \\
14 / h a\end{array}$ & $\begin{array}{c}\text { Tumutumul } \\
\text { High (HS) } \\
18 / h a\end{array}$ & $\begin{array}{c}\text { Low (LS) } \\
\text { 11/ha }\end{array}$ & $\begin{array}{c}\text { High (HS) } \\
14 / h a\end{array}$ \\
\hline $\begin{array}{l}\text { Low (LF) } \\
(250)\end{array}$ & $\mathrm{LF}+\mathrm{LS}$ & $\mathrm{LF}+\mathrm{HS}$ & $\mathrm{LF}+\mathrm{LS}$ & $\mathrm{LF}+\mathrm{HS}$ \\
$\begin{array}{c}\text { Medium (MF) } \\
(500) \\
\text { High (HF) } \\
(1000)\end{array}$ & $\mathrm{M} \mathrm{F}+\mathrm{LS}$ & $\mathrm{MF}+\mathrm{HS}$ & $\mathrm{MF}+\mathrm{LS}$ & $\mathrm{M} \mathrm{F}+\mathrm{H} \mathrm{S}$ \\
& & $\mathrm{HF}+\mathrm{LS}$ & $\mathrm{HF}+\mathrm{LS}$ & $\mathrm{HF}+\mathrm{HS}$ \\
\end{tabular}

Super-phosphate was applied annually, in February, for the 3 years 1969 to 1971 (for the subsequent 3 years an annual maintenance dressing of $250 \mathrm{~kg} / \mathrm{ha}$ was applied overall). The high rate of superphosphate $(1000 \mathrm{~kg} / \mathrm{ha})$ in the first 3 years was to test whether this was advantageous, particularly on the highly retentive Te Kuiti-Tumutumu soils. Ewes introduced as 3-year-olds were set-stocked throughout. No supplementary feed was given. Lambs were reared through to weaning and then 
removed from the trial. Ewes and lambs were shorn at weaning (late November-early December) . Measurements included monthly weighings of ewes and lambs, weekly assessments of pasture "availability" using a visual rating technique, and annual assessments of soil nutrient status and pasture composition.

\section{RESULTS AND DISCUSSION}

Results of the three years of differential topdressing 1969-71 are presented.

\section{Animal Production}

Ewe wool production and lamb data are presented in Tables 4 and 5 , respectively.

TABLE 4: WOOL PRODUCTION PER EWE AND PER HECTARE

\begin{tabular}{|c|c|c|c|c|c|c|}
\hline \multirow{2}{*}{$\frac{\text { Ewe Wool }}{\text { Main Effects }}$} & \multicolumn{3}{|c|}{ Prod./ewe (kg) } & \multicolumn{3}{|c|}{ Prod./ha (kg) } \\
\hline & 1969 & 1970 & 1971 & 1969 & 1970 & 1971 \\
\hline \multicolumn{7}{|c|}{ Te Kuiti-Tumutumu } \\
\hline Stocking rate & $\begin{array}{l}\text { LS } 4.6 \text { aA* } \\
\text { HS } 4.1 \mathrm{bB}\end{array}$ & $\begin{array}{l}3.5 \mathrm{aA} \\
3.0 \mathrm{bB}\end{array}$ & $\begin{array}{l}3.8 \mathrm{aA} \\
3.1 \mathrm{bB}\end{array}$ & $\begin{array}{l}64 \dagger \\
75\end{array}$ & $\begin{array}{l}49 \\
54\end{array}$ & $\begin{array}{l}53 \\
56\end{array}$ \\
\hline Fertilizer rate & $\begin{array}{l}\text { LF } 4.3 \text { bAB } \\
\text { M F } 4.2 \text { bB } \\
\text { HF } 4.6 \text { aA }\end{array}$ & $\begin{array}{l}3.1 \mathrm{bA} \\
3.2 \mathrm{abA} \\
3.6 \mathrm{aA}\end{array}$ & $\begin{array}{l}3.2 \mathrm{bB} \\
3.4 \mathrm{abAB} \\
3.7 \mathrm{aA}\end{array}$ & $\begin{array}{l}68 \\
67 \\
74\end{array}$ & $\begin{array}{l}48 \\
50 \\
57\end{array}$ & $\begin{array}{l}49 \\
55 \\
59\end{array}$ \\
\hline
\end{tabular}

MAHOENUI-MANGATEA

\begin{tabular}{llllllll}
\hline Stocking rate & LS 4.4 aA & $3.7 \mathbf{a A}$ & $3.8 \mathbf{a A}$ & 46 & 39 & 40 \\
& & HS 3.7 bB & $2.8 \mathbf{b B}$ & $2.8 \mathbf{b B}$ & 53 & 40 & 40 \\
Fertilizer rate & LF 3.9 a & $3.1 \mathrm{bB}$ & $3.1 \mathrm{bA}$ & 48 & 37 & 37 \\
& MF $4.2 \mathrm{a}$ & $3.4 \mathrm{aA}$ & $3.4 \mathbf{a A}$ & 53 & 42 & 42 \\
& & H F 4.0 a & $3.3 \mathrm{abAB}$ & $3.4 \mathbf{a b A}$ & 48 & 39 & 40
\end{tabular}

*Duncan's Multiple Range Test: means without a common letter differ significantly (AB, $P<0.01 ; \mathrm{ab}, P<0.05)$.

†Duncan's lettering not applicable. Effective grazing area within paddocks variable.

An indication of the relative production of the two families of soils can be obtained by comparing Te Kuiti-Tumutumu LS with Mahoenui-Mangatea HS, that is, the common stocking rate of 14 ewes/ha. All production indices showed higher gains on the former soil. 
TABLE 5: LAMBING PERCENTAGE (LAMBS DOCKED/100 EWES) AND LAMB LIVEWEIGHT GAIN (BIRTH

\begin{tabular}{|c|c|c|c|c|c|c|}
\hline Main Effects & 1969 & $\begin{array}{r}\text { Lambing } \% \\
1970\end{array}$ & 1971 & 1969 Liveweight & $\underset{1970}{\text { Gain }} \quad$ (kg/lamb) & 1971 \\
\hline $\begin{array}{l}\text { TE Kuiti-Tum } \\
\text { Stocking rate }\end{array}$ & $\begin{array}{l}\text { LS } 127 \text { a } \\
\text { HS } 142 \mathrm{a}\end{array}$ & $\begin{array}{l}105 \mathrm{aA} \\
85 \mathrm{bB}\end{array}$ & $\begin{array}{c}93 a \\
100 a\end{array}$ & $\begin{array}{l}17.7 \mathrm{aA} \\
14.3 \mathrm{bB}\end{array}$ & $\begin{array}{l}14.6 \mathrm{aA} \\
13.1 \mathrm{bA}\end{array}$ & $\begin{array}{l}17.5 \mathrm{aA} \\
14.3 \mathrm{bA}\end{array}$ \\
\hline Fertilizer rate & $\begin{array}{c}\text { LF } 144 \mathrm{a} \\
\text { MF } 132 \mathrm{a} \\
\text { HF } 128 \mathrm{a}\end{array}$ & $\begin{array}{r}88 \mathrm{a} \\
94 \mathrm{a} \\
104 \mathrm{a}\end{array}$ & $\begin{array}{c}92 \mathrm{a} \\
96 \mathrm{a} \\
102 \mathrm{a}\end{array}$ & $\begin{array}{l}14.8 \mathrm{bB} \\
15.5 \mathrm{bAB} \\
17.8 \mathrm{aA}\end{array}$ & $\begin{array}{l}12.9 \mathrm{bA} \\
13.6 \mathrm{abA} \\
15.0 \mathrm{aA}\end{array}$ & $\begin{array}{l}13.7 \mathrm{bA} \\
16.7 \mathrm{abA} \\
17.1 \mathrm{aA}\end{array}$ \\
\hline \multicolumn{7}{|c|}{ M AHOENUI-M ANGATEA } \\
\hline Stocking rate & $\begin{array}{l}\mathrm{LS} 124 \mathrm{aA} \\
\mathrm{HS} 111 \mathrm{bA}\end{array}$ & $\begin{array}{r}106 \mathrm{a} \\
85 \mathrm{a}\end{array}$ & $\begin{array}{r}121 \mathrm{aA} \\
94 \mathrm{bA}\end{array}$ & $\begin{array}{l}17.7 \mathrm{aA} \\
14.7 \mathrm{bA}\end{array}$ & $\begin{array}{l}14.0 \mathrm{aA} \\
10.8 \mathrm{bB}\end{array}$ & $\begin{array}{l}17.3 \mathrm{aA} \\
13.2 \mathrm{bB}\end{array}$ \\
\hline Fertilizer rate & $\begin{array}{l}\text { LF } 108 \mathrm{bA} \\
\text { MF } 120 \mathrm{abA} \\
\text { HF } 124 \mathrm{aA}\end{array}$ & $\begin{array}{l}99 \mathrm{a} \\
94 \mathrm{a} \\
95 \mathrm{a}\end{array}$ & $\begin{array}{l}111 \mathrm{abA} \\
123 \mathrm{aA} \\
89 \mathrm{bA}\end{array}$ & $\begin{array}{l}16.9 \mathrm{a} \\
15.9 \mathrm{a} \\
15.8 \mathrm{a}\end{array}$ & $\begin{array}{cc}12.3 & \mathrm{a} \\
12.1 & \mathrm{a} \\
12.9 \mathrm{a}\end{array}$ & $\begin{array}{l}14.9 \mathrm{a} \\
15.1 \mathrm{a} \\
15.5 \mathrm{a}\end{array}$ \\
\hline
\end{tabular}


Stocking rates varied by 4 ewes/ha between HS and LS on both trials. Production per animal declined markedly at the high stocking rate, so much so that production per hectare in years 1970, 1971 (Table 4) differed little from that at the low stocked treatments. Overstocking is indicated. At the low stocking rates (10 and 14 ewes/ha, respectively) feed was always abundant. These rates are still above the district average (D. B. Wright, pers. comm.) . Replacement stock, however, are not included in the trials.

Mean lambing percentage (Table 5) varied between years but averaged 108 over the 3 years. Lamb deaths between birth and docking (data not presented) averaged 18\%, even though intensive shepherding was practised. Lamb liveweight gains between birth and weaning (Table 5) again show the greater production potential of the Te Kuiti-Tumutumu soil compared with Mahoenui-Mangatea. Superphosphate responses are evident, in terms of liveweight gain, on the former soil but not on the latter. Limitations are imposed on the data by uneven lamb numbers among treatments.

RESPONSE TO SUPERPHOSPHATE

Response to superphosphate, as measured through ewe liveweight and pasture "availability" is shown in Fig. 3, as a mean of both HS and LS.

Marked responses to increasing rates of superphosphate were evident on Te Kuiti-Tumutumu soils. No responses occurred on Mahoenui-Mangatea soils (above $250 \mathrm{~kg} / \mathrm{ha}$ ) in 1969 and 1970, although slight responses (sig. 5\%) were apparent in 1971.

Rainfall 'averaged $1330 \mathrm{~mm}$ (53 in.) over the three years. Of particular interest was rhe low rainfall recorded over the October 1969 to April 1970 period $(425 \mathrm{~mm})$, resulting in severe drought conditions.

\section{Stocking Rate and Fertilizer Response on Te Kuiti-Tumutumu}

The importance of stocking rate as it affects the efficiency of pasture utilization has been demonstrated (McMeekan and Walshe, 1963). Similarly, in using fertilizer to increase pasture production additional stock must be provided to utilize efficiently the extra feed produced. Table 6 shows mean wool production per animal (1969-71) on Te Kuiti-Tumutumu soil at two stocking and fertilizer rates. 


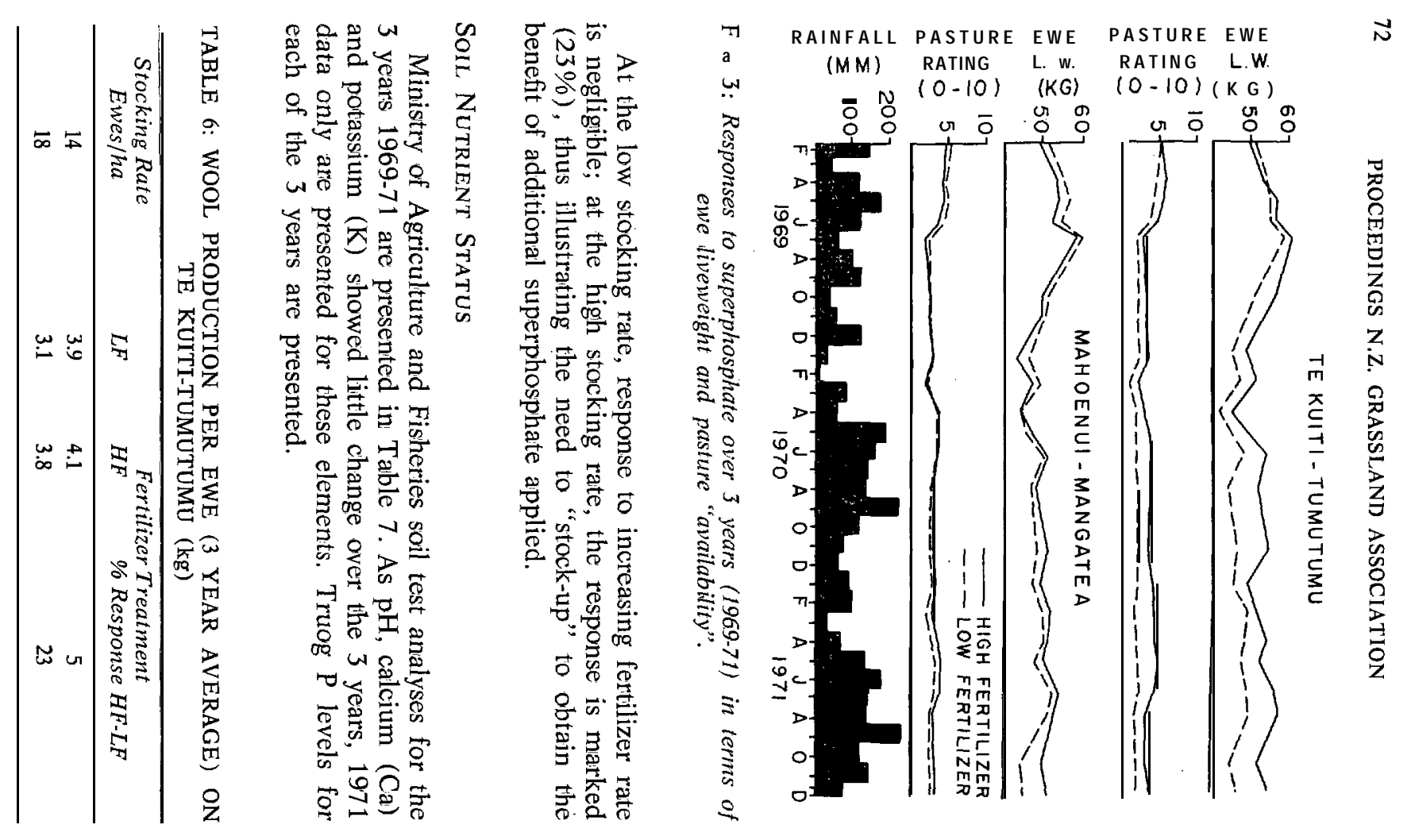


FERTILIZER AND STOCKING RATES

TABLE 7: MINISTRY OF AGRICULTURE \& FISHERIES

SOIL TESTS $(0-7.5 \mathrm{~cm})$

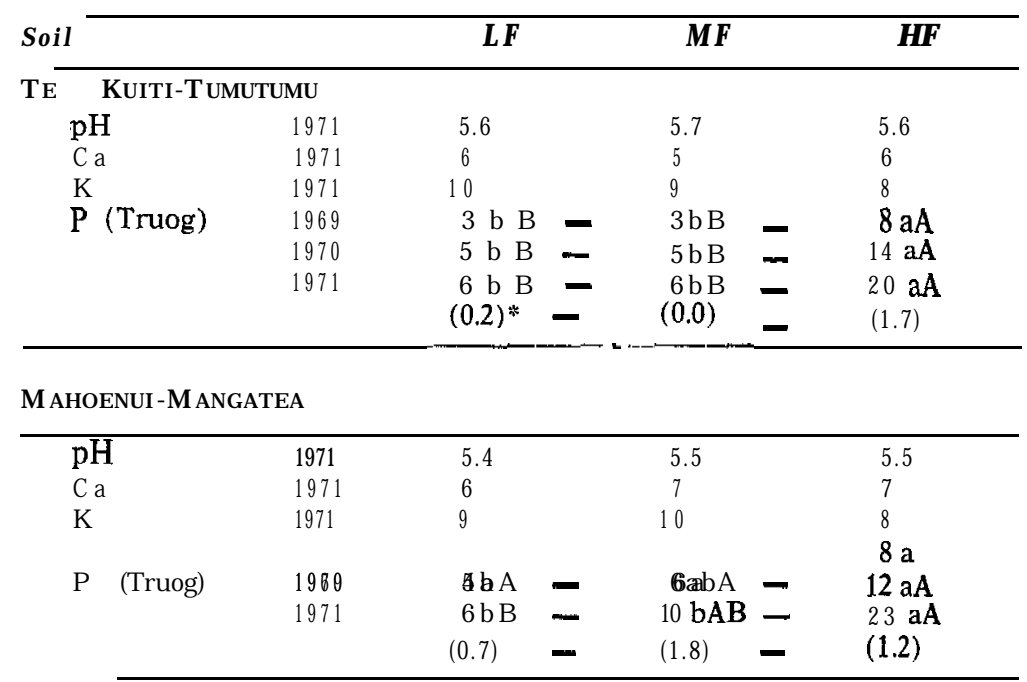

$* 7.5-15 \overline{\mathrm{cm}}$

For Te Kuiti-Tumutumu soils there has been little change in Truog $\mathrm{P}$ within years between LF and MF but a marked change between MF and HF. For Mahoenui-Mangatea, Truog $\mathrm{P}$ varied little between LF and MF in 1969 and 1970, but showed a significant increase in 1971. A marked change from MF to HF was evident in 1970 and 1971.

Absence of shift in Truog $\mathrm{P}$ in Te Kuiti-Tumutumu soils between LF and MF is undoubtedly due to the presence of high phosphate-fixing clays. High Truog $\mathrm{P}$ levels under HF are probably a measure of phosphate ions before their eventual fixation by clays. Measurements taken since differential topdressing ceased confirm a definite drop in Truog $\mathrm{P}$ on $\mathrm{HF}$.

Mention should be made of lack of movement of applied $\mathrm{P}$ through the profile (Table 7) . Even where a total of $3000 \mathrm{~kg} / \mathrm{ha}$ of superphosphate had been applied, levels of only 1.2 to 1.7 in the 7.5 to $15 \mathrm{~cm}$ layer were recorded.

PASTURE COMPOSITION

Species composition before trial commencement ( 1968) and after 3 years (1971) is presented in Table 8. 
TABLE 8: PASTURE COMPOSITION CHANGES 1968-71 (Cover hits $/ 100$ points)

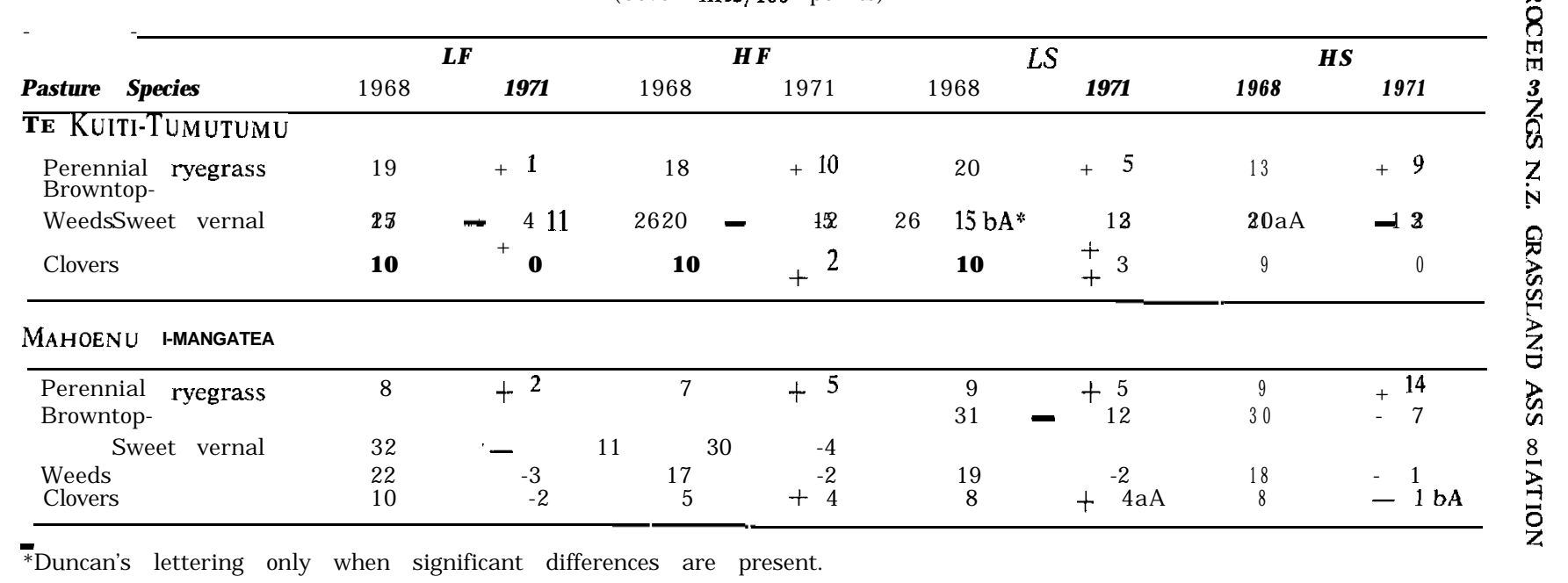

*Duncan's lettering only when significant differences are present. 
Browntop, sweet vernal, and weed species make a major contribution to total species present. In general, these provide a higher proportion of total species present on Mahoenui-Mangatea than on Te Kuiti-Tumutumu.

Treatment effects on species composition have been negligible. Although occasional stocking rate effects have occurred (sig. $5 \%$ ) high rates of superphosphate have shown no measurable improvement in species composition. Certainly percentage clover in the sward (of which 30 to $40 \%$ is Trifolium dubium, suckling clover) has not improved. Some criticism could be levelled at the time at which this measurement was taken (August), although other measurements of hill country swards would tend to confirm these low clover levels. Obviously management in addition to fertilizer, has an important role to play in sward improvement. Parker (1972), for instance, showed that intensive block grazing with breeding cows on Taranaki hill pastures markedly improved white clover content. Other practices may need devising to suit local conditions.

\section{ECONOMIC CONSIDERATIONS}

In an economic assessment" of fertilizer rates on the trial (P. G. Yeoman, pers. comm.) payable responses in terms of animal production were obtained to rates up to $500 \mathrm{~kg} / \mathrm{ha}$ of superphosphate on Te Kuiti-Tumutumu with no response above the lowest rate $(250 \mathrm{~kg} / \mathrm{ha})$ on Mahoenui-Mangatea (1970-1 or 1972-3 values), These results were applicable to the high stocking rate treatments only.

\section{CONCLUSIONS}

(1) Parent materials such as volcanic ash and siltstone and sandstone form soils which differ markedly in their physical and chemical properties.

(2) Soil complexes, rather 'than uniform soil types, tend to predominate in this hill country. Patterns of soil distribution have been established.

(3) Marked differences are apparent in pasture production,, stock carrying capacity and response to superphosphate between soils derived from volcanic ash (yellow-brown loams) and sandstone siltstone (yellow-brown earths) .

*Increased variable costs associated with higher stocking and fertilizer rates were deducted from 'increased income assessed by valuing the improved production obtained. 
(4) Stocking rates of 15 and 18 ewes/ha are possible on Mahoenui-Mangatea and Te Kuiti-Tumutumu, respectively, under trial conditions and a set-stocking management. Such rates would need to be modified to the on-farm situation where replacement sheep and probably cattle would be run.

(5) Improvement in per-animal performance or stocking rate may be possible by adopting techniques of sward improvement and stock management.

(6) Where feasible, differential topdressing should be practised. Te Kuiti-Tumutumu should receive $500 \mathrm{~kg} / \mathrm{ha} / \mathrm{yr}$ of superphosphate, Mahoenui-Mangatea $250 \mathrm{~kg} / \mathrm{ha} / \mathrm{yr}$. These rates could be 'applied by aircraft making double runs over the Te Kuiti-Tumutumu soils. Effective utilization of the pasture produced is necessary.

\section{ACKNOWLEDGEMENTS}

Thanks are due to H. R. Foskett and J. W. Tarrant for trial conduct; to B. Andrews, W. L. Osborn, R. R. Sherlock, D. B. Wright, and P. G. Yeoman for assistance in setting up and operating the trial; to D. F. Wright for statistical analyses; and to the farmer, David Easton, for his willing co-operation at all times.

\section{REFERENCES}

McMeekan, C. P.; Walshe, M. J., 1963: J. agric. Sci, Camb., 61: 147-66.

N.Z. Soil Bureau, 1954: Soils of the North Island, New Zealand. N.Z. -Soil Bur. Bull, 5.

Parker, B. W., 1972: Proc. Ruakura Fmrs' Conf.: 24-35.

Saunders, W. M. H., 1965: N.Z. $/ l$ agric. Res., 8: 30-57. 